... Miha Humar: Influence of Norway Spruce and European Larch Heartwood Ring-Width...

Miha Humar ${ }^{1}$

\title{
Influence of Norway Spruce and European Larch Heartwood Ring-Width on Extractive Content and Durability
}

\section{Utjecaj širine goda na sadržaj ekstraktivnih tvari i trajnost srži norveške jele i europskog ariša}

Original scientific paper $\bullet$ Izvorni znanstveni rad

Received-prispjelo: 10. 9. 2012.

Accepted-prihvaćeno: 15. 2. 2013.

UDK: 630*811.4; 630*.813.2; 674.032.475.34; 674.032.475.54

doi:10.5552/drind.2013.1244

\begin{abstract}
Norway spruce and European larch wood are among the most important species for construction applications in central Europe. In order to assess the influence of the ring-widths and presence of the extractives on the performance of these wood species against wood decays fungi, Soxlet extracted and non-extracted spruce and larch wood specimens with different ring-widths were exposed to three brown rot fungi according to the EN 113 procedure. In parallel spruce and larch wood specimens were exposed in field test sites in use class 3 conditions according to the double layer procedure. The results showed that ring-widths do not influence the performance of the spruce and larch heartwood against brown rot fungi in laboratory conditions, but on the other hand have influence on the performance of spruce wood in field test setup. Additionally, extraction does not have an influence on the durability of spruce wood, but has an influence on the durability of larch wood.
\end{abstract}



SAŽETAK • Norveška jela i europski ariš među najvažnijim su vrstama čije se drvo upotrebljava u graditeljstvu u središnjoj Europi. Kako bi se procijenio utjecaj širine goda i sadržaj ekstraktivnih tvari na otpornost tih vrsta drva na gljive truležnice, uzorci od ekstrahiranoga i neekstrahiranog drva jele i ariša izloženi su trima gljivama smeđe truleži prema postupku definiranom normom EN 113. Uzorci drva jele i ariša usporedno su bili izloženi na ispitnim mjestima uz primjenu uvjeta klase 3, u skladu s postupkom dvostrukog sloja. Rezultati su pokazali da širina goda ne utječe na otpornost drva srži jele i ariša na gljive smeđe truleži u laboratorijskim uvjetima, ali utječe na otpornost jelova drva u terenskim uvjetima. Osim toga, ekstrakcija nema utjecaja na trajnost drva jele, ali ima utjecaj na trajnost drva ariša.

Ključne riječi: Picea abies, Larix decidua, gljive truležnice, ekstrakcija, otpornost, laboratorijskitest, terenska ispitivanja

\footnotetext{
${ }^{1}$ Author is associate professor at University of Ljubljana, Biotechnical Faculty, Department of Wood Science and Technology, Ljubljana, Slovenia.
} 


\section{INTRODUCTION}

\section{UVOD}

Norway spruce and Larch are among the most important central European wood species and they are frequently used for construction applications. The main part of all sawn timber is used in constructions that are not in immediate ground contact. One of the issues that limit outdoor use of spruce wood is insufficient durability (Brischke and Rapp, 2008). On the contrary, larch, especially European larch, has traditionally held a good reputation in the Alps as a source of building material. This reputation is based upon its excellent mechanical properties combined with its good natural durability out of soil contact (Collardet and Besset, 1988; Flæte et al., 2011). Besides wood quality, it seems obvious that the longevity of these constructions also relies on a high ancestral level of building expertise. Furthermore, the apparent natural durability and longevity qualities of larch wood do not seem to be expressed in the same way outside its distribution within the Alps (Curnel et al., 2008). Consequently, larch from the warmer, more fertile regions of the lowlandssometimes performs considerably worse than larch from the Alps. However, some of the authors reported, that durable larch wood can be found even in the lowland plantations in Eastern Europe (Curnel et al., 2008).

Natural durability, or alternatively decay resistance, is defined as the ability of wood to resist biological degradation (Eaton and Hale, 1993). Brown-rot decay is a common and very destructive type of decay of sawn softwoods in central Europe. Brown-rot fungi utilize the cellulose and hemicelluloses of the cell wall, leaving the lignin essentially undigested, albeit modified by demethylation and oxidation (Green and Highley, 1997). As a consequence the attacked wood darkens, shrinks, and breaks into brick-shaped pieces, leading to rapid structural failure (Solár et al., 2007).

Larch and spruce wood are known as species with extreme variations of wood properties. Significant variability existed amongst the larch and spruce originating from non-autochthonous lowland locations (Brischke et al., in press). Local growth conditions, age and maturity of wood may be more relevant than genetic effects (Venäläinen et al., 2001). One of the factors that reflect the local growth conditions of coniferous wood species is ring-width. On a macroscopic level, it has been proven for several times that ringwidth (and related density) is an important parameter predicting the mechanical properties of wood. According to Verkasalo (1992) MOE of conifer wood species increases with increasing density, number of growth rings per cross-sectional unit area, and increasing latewood percentage. On the contrary, there is less information on the performance of spruce wood against wood decay fungi regarding the ring-width, therefore this issue was elucidated in this paper.

Heartwood extractives play a key role for natural durability, besides lignification and growth characteristics. The significance of heartwood extractives for natural durability was demonstrated as early as 1924
(Hawley et al., 1924). Larch heartwood contains high amounts of extractives; the major part consists of arabinogalactan, a water-soluble and heavily branched polysaccharide comprising 5\% to $30 \%$ of the total by weight (Cote et al., 1966). The high amounts of arabinogalactan are specific to larch; they are found primarily in the cell lumen and their role remains unclear (Cote et al., 1966). In brown-rot decay, it may even enhance fungal growth by being a nutrient source (Srinivasan et al., 1999). Besides arabinogalactan, up to $3.5 \%$ flavonoids are found in larch heartwood (Giwa and Swan, 1975), which may play a role in decay resistance. Among various extractives, phenolic extractives exhibited the highest biological activity (Gierlinger et al., 2004).Triglycerides, steryl esters, free sterols, resin acids, diterpene alcohols and free fatty acids are predominant extractives characterized in water based solvents (Örsaet al., 1997). Triglycerides are the most important extractives in sapwood, while resin acids are reported as predominant extractives in Spruce heartwood (Hovelstad et al., 2006).

Several methods have been used to test the performance of wood species against wood decay fungi. In general, methods can be divided into laboratorial and field tests. Laboratory methods provide more comparable data and on the other hand reflect only the fungicidal or fungistatic properties of wood and do not reflect other important factors that influence the performance of the wood in real applications, like water repellence, sorption properties, etc. On the contrary, field test data reflect overall performance of the material, but it takes a considerably longertime to obtain the results.

The aim of this study was to elucidate the influence of the ring-width on the extractive content and performance of spruce and larch wood against wood decay fungi. These data are important both from the scientific and application point of view, as this is the key information for sorting and grading of sawn wood.

\section{MATERIAL AND METHODS}

\section{MATERIJAL I METODE}

For testing, various different Norway spruce ( $P i$ cea abies) and European larch (Larix decidua)heartwood, semi-radial boards with different ring-widths were chosen. They were classified according to the ring-width into two groups for spruce and two groups for larch wood specimens (Table 1) and afterwardsdensity of the oven dry wood was determined. Samples originate from different boards. Spruce wood specimens were made of 6 different boards, and 4 boards were used for the preparation of larch specimens. Two types of specimens were obtained from the boards. The bigger ones $(2.5 \mathrm{~cm} \times 5.0 \mathrm{~cm} \times 50 \mathrm{~cm})$ were used for field testing according to the Horizontal double layer test (Rapp and Augusta, 2004; Augusta, 2007) and smaller ones $(1.5 \mathrm{~cm} \times 2.5 \mathrm{~cm} \times 5.0 \mathrm{~cm})$ for standard laboratory testing (EN 113, 2004). Laboratory tests were performed on larch and spruce wood specimens, while field tests were only performed on selected spruce and larch wood specimens. 
Before exposure to fungi, half of the smaller specimens were extracted according to the Soxlet procedure usingthe following solvents: cyclohexane/ethanol (22 h), ethanol (22 h) and water (44 h) in automatic extraction system Büchi B-811. Extracted and non-extracted samples were oven-dried at $103+2{ }^{\circ} \mathrm{C}$ until a constant weight was achieved. Percentage of extractives was determined gravimetrically and expressed in percentages. Mass and dimensions of the oven dried specimens were determined and used for density calculations.

Thereafter, specimens were steam sterilized $\left(121^{\circ} \mathrm{C}\right.$ ) and exposed to threebrown rot fungi (Antrodia vaillantii, Serpula lacrymans and Gloeophyllum trabeum) for 16 weeks according to the EN 113 procedure (2004). These wood decay fungi are predominant decomposers of spruce wood in commercial applications (Schmidt, 2007). Two specimens, one extracted and one non-extracted, were randomly exposed in the same experimental jar. After fungal exposure, specimens were isolated, oven-dried and weighed again. For comparison, Scots pine sapwood specimens (Pinus sylvestris)) were exposed to fungi as well. The experiment was performed with five replicate specimens per fungus / ring-width.

In parallel, FTIR analysis of the wood was performed. DRIFT spectra were collected between 4000 cm-1 and $450 \mathrm{~cm}-1$ with the Perkin Elmer FTIR Spectrum One Spectrometer, using the Abrasive Pad 600 Grit-Coated, PK/100 (Perkin Elmer) paper.

In parallel, spruce wood specimens divided into two groups (Table 1) were exposed in use class 3 conditions according to the double layer test method (Rapp and Augusta, 2004; Augusta 2007). 10 specimens were grouped together in double layer test setup $500 \mathrm{~mm}$ above ground. Decay was visually evaluated and rated (0 - no attack; 1 - slight attack; 2 - moderate attack; 3
Table 1 Properties of Norway spruce (Picea abies) and European larch wood (Larix decidua) obtained for small specimens, used for laboratory decay tests.

Tablica 1. Svojstva drva norveške jele (Picea abies) i europskog ariša (Larix decidua) dobivena za male uzorke korištene za laboratorijski test truljenja

\begin{tabular}{|l|c|c|c|}
\hline \multirow{2}{*}{$\begin{array}{c}\text { Woodspecies } \\
\text { Vrsta drva }\end{array}$} & $\begin{array}{c}\text { Ring- } \\
\text { width } \\
\text { Širina goda } \\
\mathrm{mm}\end{array}$ & $\begin{array}{c}\text { Density } \\
\text { Gustoća } \\
\mathrm{kg} / \mathrm{m}^{3}\end{array}$ & $\begin{array}{c}\text { Extractive } \\
\text { content / Sadržaj } \\
\text { ekstraktivnih tvari } \\
\%\end{array}$ \\
\hline \multirow{2}{*}{$\begin{array}{c}\text { Norway spruce } \\
\text { norveška jela }\end{array}$} & $2-4$ & 431 & 2.98 \\
\cline { 2 - 4 } & $4-6$ & 382 & 3.65 \\
\hline $\begin{array}{l}\text { Larch } \\
\text { ariš }\end{array}$ & $2-4$ & 525 & 3.98 \\
\hline $\begin{array}{l}\text { Pine sapwood } \\
\text { bjeljika bora }\end{array}$ & $2-5$ & 420 & 5.83 \\
\cline { 2 - 4 } & & 532 & 6.69 \\
\hline
\end{tabular}

severe attack; 4 - failure) every year as prescribed by EN 252 standard (1989).

\section{RESULTS AND DISCUSSION 3. REZULTATI I RASPRAVA}

The material used in this experiment was representative and originating from the northern Slovenia in order to limit the influence of the climate conditions on wood properties. As expected, correlation was determined between spruce wood density and ring-width. Density of the dry spruce wood varied between $327 \mathrm{~kg} / \mathrm{m}^{3}$ for specimens with the ring-width between $4 \mathrm{~mm}$ and 6 $\mathrm{mm}$, and $431 \mathrm{~kg} / \mathrm{m}^{3}$ for spruce wood with the narrowest rings (up to $2 \mathrm{~mm}$ ) (Table 1 ). Density of the larch heartwood was slightly higher, and varied between $525 \mathrm{~kg} / \mathrm{m}^{3}$ and $532 \mathrm{~kg} / \mathrm{m}^{3}$. These results are in line with the values reported in the literature (Wagenführ, 1996).

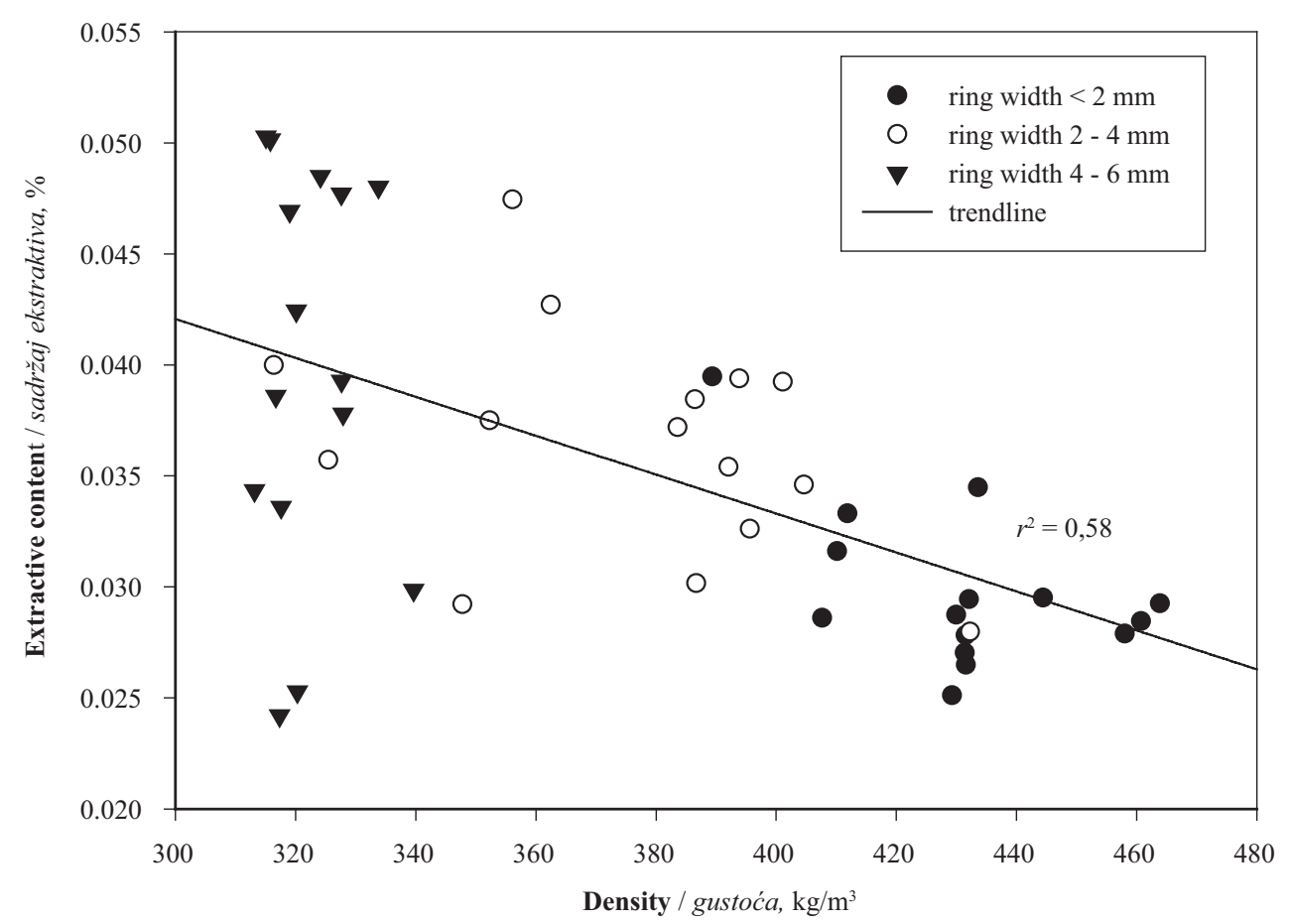

Figure 1 Relationship between density and extractive content ofNorway spruce wood specimens with different ring-widths Slika 1. Odnos između gustoće i sadržaja ekstraktivnih tvari u uzorcima drva norveške jele različitih širina godova 


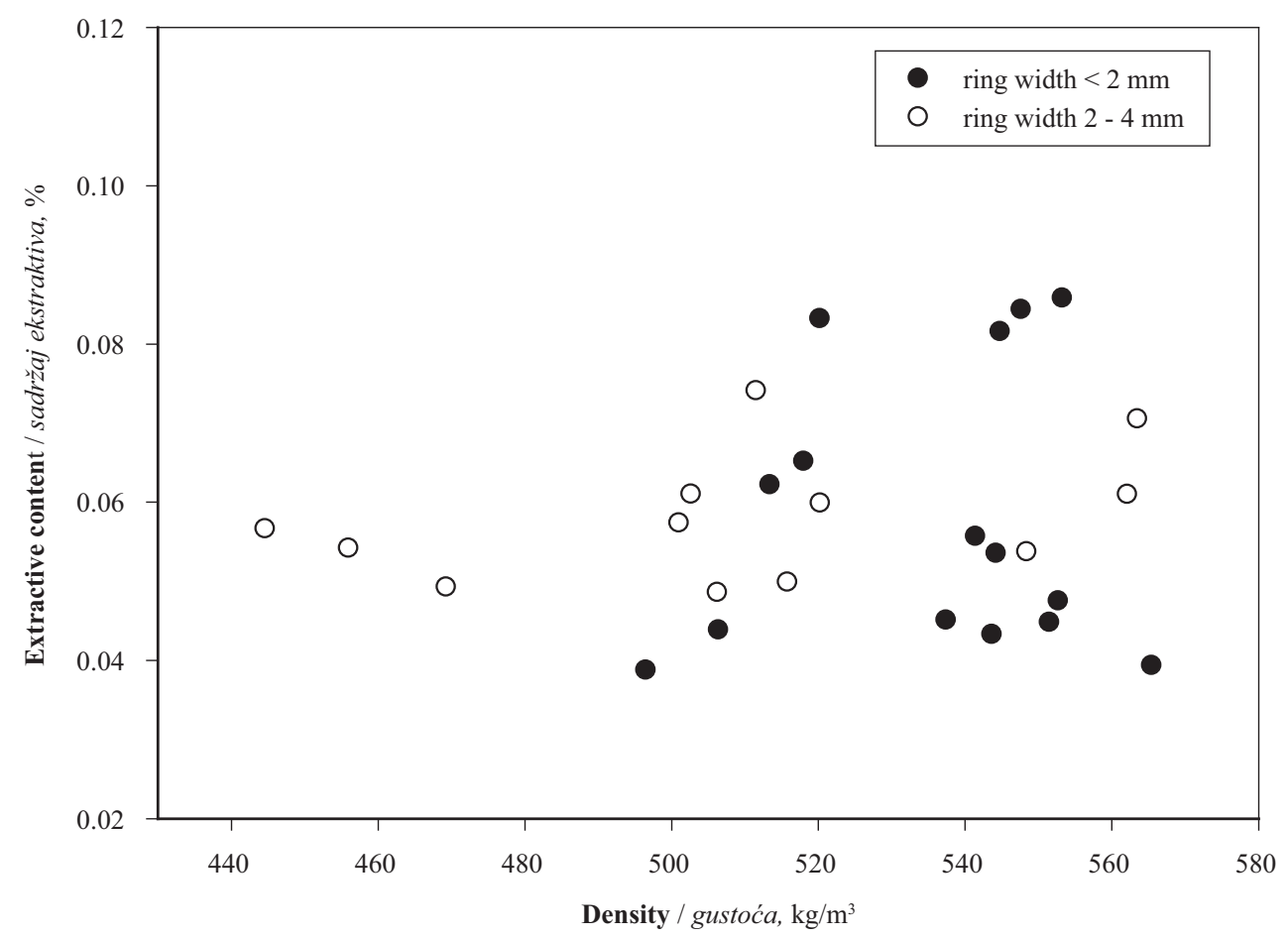

Figure 2 Relationship between density and extractive content of larch heartwood specimens with different ring-widths Slika 2. Odnos između gustoće i sadržaja ekstraktivnih tvari u uzorcima od srži drva ariša različitih širina godova

Extractive content varied within the samples, as well. The data presented in Table 1 and 2 show that with the increasing density (narrow ring-width), the extractive content in spruce wood samples does not increase and, on the contrary, it even decreases. However, this correlation is not very tight, and there is huge scattering predominantly in the less dense spruce wood specimens (Figure 1). The equation expressingthe amount of extractives per volume of material (spruce), showed that there is a comparable amount of the extractives per given volume of the material. Similar relation is also observed with larch specimens. Specimens with the wider rings contain more extractives than parallel ones with narrower rings (Table 1). If at least a weak correlation was detected between density and extractive content with spruce specimens, no such correlation was observed between these two parameters with larch wood specimens (Figure 1 and 2). Another issue to be considered at this point is that larch wood specimens contain higher amountsof the extractives $(6.3 \%)$ than spruce ones $(3.5 \%)$. However, the performance of the respective wooden materials is not only defined by the concentration, composition or biological activity of the extractives. In parallel,wood FTIR spectra were determined. As shown inFigure 3, there was actually no difference in the FTIR spectra of spruce wood regarding the ring-width difference. No influence of the ring-width can be seenin FTIR spectra of larch wood either. The main reason for this is the fact that IR assignments of the extractives are similar or even the same as the assignments of lignin. Therefore, chemical changes of the extractives in wood cannot be determined with FTIR spectroscopy.

However, the most important question addressed in this paper was, how density or ring-width and ex- tractive content define the performance of wood against brown rot fungi. Brown rot fungi were chosen, as softwood species are predominately degraded by brown rot fungi (Green and Highley, 1997). Mass loss of the pine sapwood specimens that was used as a virulence control clearly indicates that the fungi were active. After 16 weeks of exposure, those specimens lost between $48.6 \%$ (G. trabeum) and $27.6 \%$ (A. vaillantii). If these data are compared with mass losses of spruce wood, it can be seen that the mass losses of spruce wood are lower compared to pine sapwood, whichis in line with better natural durability of spruce wood (EN 350-1, 1994). Similarly as pine sapwood, G. trabeum was



Wave number / valna duljina, $\mathrm{cm}^{-1}$

Figure 3 FTIR spectra of non-extracted spruce wood with narrow ring widths (dotted line) and the widest ring widths (solid line)

Slika 3. FTIR spektar za neekstrahirano drvo jele uskih godova (točkasta linija) i najširih godova (puna linija) 
... Miha Humar: Influence of Norway Spruce and European Larch Heartwood Ring-Width...

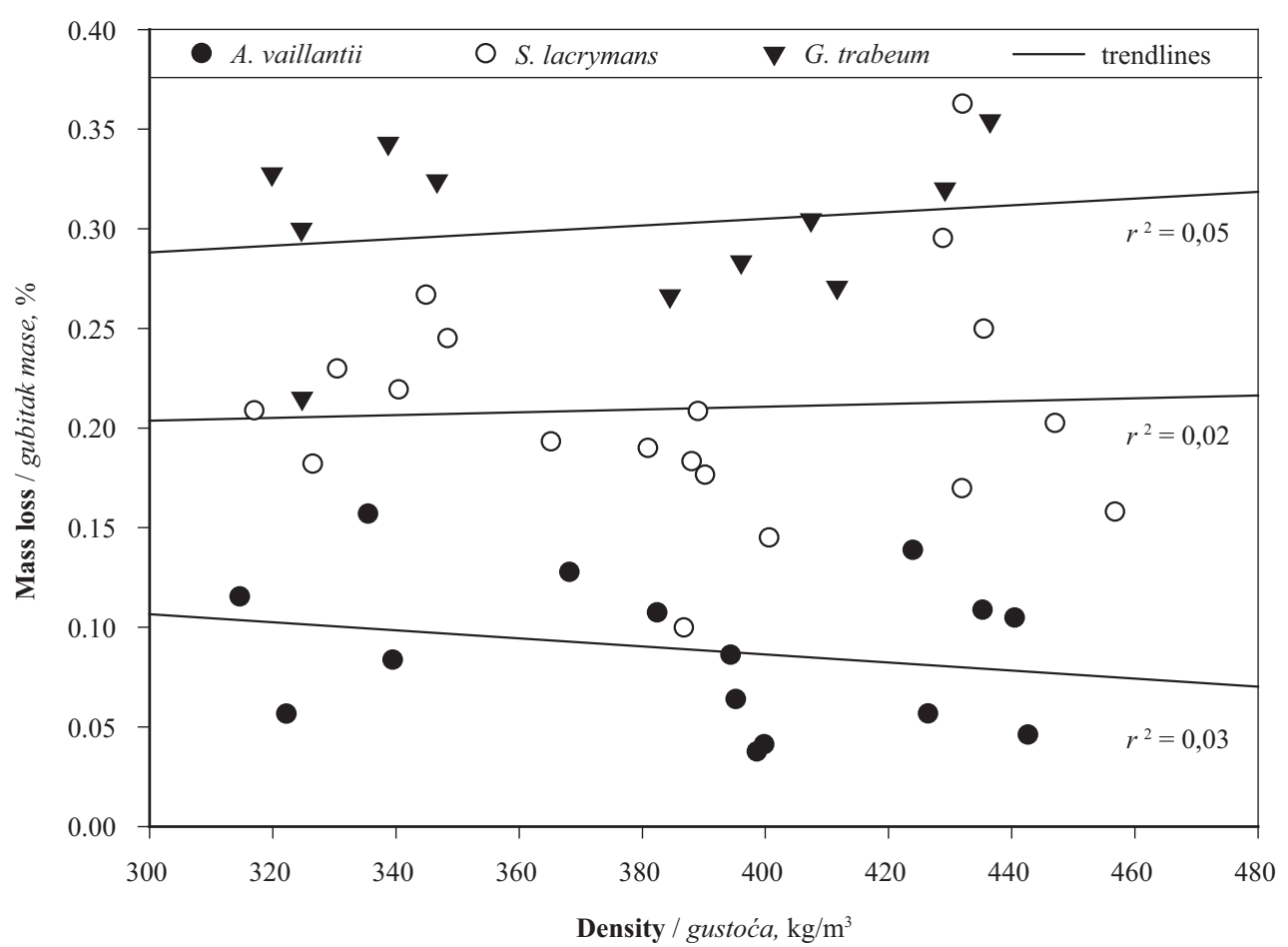

Figure 4 Relationship between density of Norway spruce wood and mass loss after 16 weeks of exposure to the respective brown rot fungi

Slika 4. Odnos između gustoće drva norveške jele i gubitka mase nakon 16 tjedana izlaganja odgovarajućim gljivama smeđe truleži

found the most aggressive, followedby $S$. lacrymans and $A$. vaillantii (Table 2). However, if comparison is made between the ring-width (Table 2) or density (Figure 4) of the specimens and the mass loss of the specimens, it can be seen that there is no correlation between the ring-width or density and mass loss after exposure to the fungi.Comparison of the extracted and non-extracted specimens showed that there is no statistically significant difference between mass loss of the extracted and non-extracted spruce wood specimens. This indicates that the extractives in spruce wood do not have very prominent effect on the natural durability of this wood species.

In contrasts to spruce and pine sapwood specimens, larch heartwood exhibited better performance against brown rot fungi. Mass losses of larch wood specimens were lower by approximately $50 \%$ compared to pine wood controls (Table 2). This confirms better durability of larch heartwood (durability class 3-4) compared to spruce (durability class 4) and pine sapwood (durability class 5) (EN 350-1, 1994).In contrast to spruce wood specimens, extracted larch wood was more susceptible to brown rot decay than non extracted larch wood. This was evident in all groups of the specimens with exception of larch wood with narrow ring-width exposed to $A$. vaillantii (Table 2), indicating that larch extractives play an important role byenabling durability. Similarly as the presence of extractives, ring width (or heartwood density) does not have significant influence on the durability of larch wood, ascan be seen in Figure 5. On the other hand, the extracted larch heartwood was still much more durable

Table 2 Influence of spruce and larch ring-width on the performance of respective heartwood against brown rot fungi; Scots pine sapwood was used as virulence control

Tablica 2. Utjecaj širine goda jele i ariša na otpornost drva srži na gljive smeđe truleži; bjeljika bora služila je kao kontrolni uzorak

\begin{tabular}{|c|c|c|c|c|c|c|c|}
\hline \multirow{5}{*}{$\begin{array}{l}\text { Wood species } \\
\text { Vrsta drva }\end{array}$} & \multirow{5}{*}{$\begin{array}{c}\text { Ring-width } \\
\text { Širina goda } \\
\mathrm{mm}\end{array}$} & \multicolumn{6}{|c|}{ Wood decay fungi / Gljive truležnice } \\
\hline & & \multicolumn{2}{|c|}{ G. trabeum } & \multicolumn{2}{|c|}{ S. lacrymans } & \multicolumn{2}{|c|}{ A. vaillantii } \\
\hline & & \multicolumn{6}{|c|}{ extracted before exposure / ekstrahirano prije izlaganja } \\
\hline & & yes / da & no / ne & yes / da & no / ne & yes / da & no / ne \\
\hline & & \multicolumn{6}{|c|}{ Mass loss, \% / gubitak mase, $\%$} \\
\hline \multirow{3}{*}{ Norway spruce / norveška jela } & $<2$ & 30.7 & 31.2 & 16.6 & 23.3 & 14.4 & 9.1 \\
\hline & $2-4$ & 27.1 & 29.8 & 18.9 & 16.8 & 7.3 & 6.7 \\
\hline & $4-6$ & 25.2 & 29.2 & 24.2 & 22.5 & 11.9 & 10.8 \\
\hline \multirow{2}{*}{ Larch / ari $\check{s}$} & $<2$ & 17.5 & 15.5 & 11.4 & 13.9 & 6.3 & 4.4 \\
\hline & $2-4$ & 20.6 & 16.1 & 14.4 & 8.9 & 6.8 & 3.7 \\
\hline Pine sapwood / bjeljika bora & $2-5$ & & 48.6 & & 42.1 & & 27.6 \\
\hline
\end{tabular}




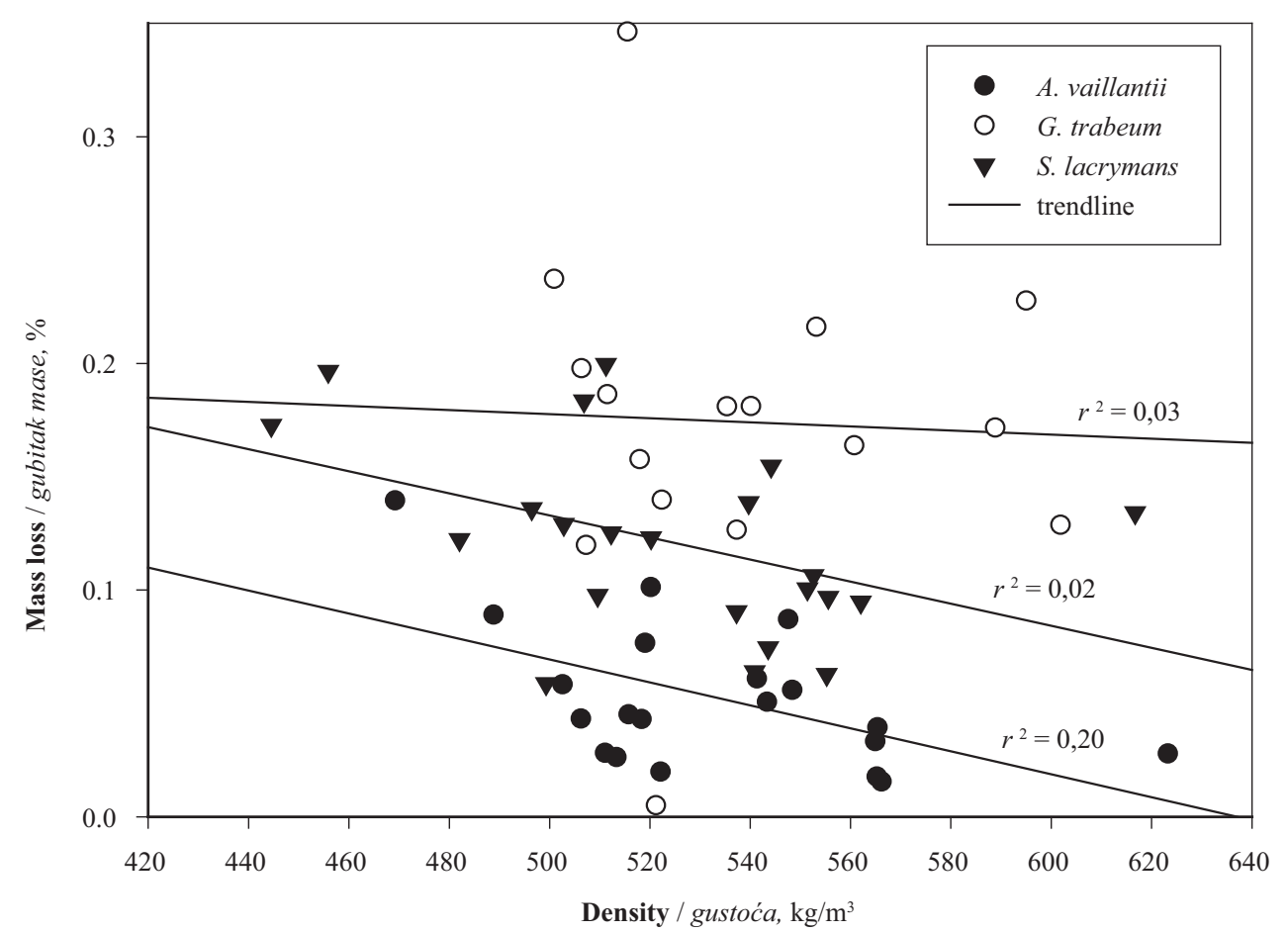

Figure 5 Relationship between density of larch heartwood and mass loss after 16 weeks of exposure to the respective brown rot fungi

Slika 5. Odnos između gustoće drva srži ariša i gubitka mase nakon 16 tjedana izlaganja odgovarajućim gljivama smeđe truleži

than spruce wood or pine wood. Thus, it is believed that this is another proof that natural durability of the wood cannot be explained by the presence or absence of the extractives, and that there must be some other mode of action that influences durability. One of the mechanisms that might affect the durability is the efficacy of water exclusion (Welzbacher et al., 2009).

In order to overcome limitations of the laboratory tests, parallel specimens were exposed to the field test sites in above ground conditions. As it is considerably more difficult to obtain bigger specimens with homogeneous ring-widths, only two types of spruce wood specimens, and one type of larch wood specimens were exposed. As clearly shown in Table 3, the first signs of fungal decay appeared on spruce wood after the first year of exposure, while there was no decay on larch wood even after four years of exposure. Additionally, comparison of spruce wood samples with different ring-widths revealed that the specimens with wider ring-widths were completely decayed after four years of exposure, while the specimens with narrow ringwidth were still not completely degraded after 6 years of exposure (Table 3). With both specimens, Gloeophyllum sp. was the prevalent reason for the degrada- tion, as indicated by the fruiting bodies present. This field test proves better natural durability of spruce wood with narrow ring-widths compared to the ones with wide ring-widths. Furthermore, comparison of the field test data and laboratory data showed that the laboratory tests sometimes underestimate the performance of durable materials against wood decay fungi. Therefore, field tests are recommended in order to assess the actual performance of the material.

\section{CONCLUSIONS \\ 4. ZAKLJUČCl}

Performance of spruce and larch heartwood with different ring-widths in standard fungal laboratory test does not show a significant influence of the durability against brown rot fungi. In contrast, field test data proved the influence of the ring-widths on the performance of spruce wood against fungi. Furthermore, extraction of spruce wood specimens,before fungal exposure, has no influence on the performance against wood decay fungi either. On the contrary, extraction of larch heartwood specimens hasa much more prominent influence on the fungal resistance.

Table 3 Performance of Norway spruce wood in outdoor test (use class 3 condition), according to double layer protocol Tablica 3. Otpornost drva norveške jele u testu na otvorenome (u uvjetima klase 3), prema protokolu dvostrukog sloja

\begin{tabular}{|c|c|c|c|c|c|c|c|c|}
\hline \multirow{3}{*}{$\begin{array}{l}\text { Wood species } \\
\text { Vrsta drva }\end{array}$} & \multirow{3}{*}{$\begin{array}{c}\text { Ring-width } \\
\text { Širina goda } \\
\text { mm }\end{array}$} & \multirow{3}{*}{$\begin{array}{l}\text { Beginning of exposure } \\
\text { Početak izlaganja }\end{array}$} & \multicolumn{6}{|c|}{ Year of rating / Godina ocjenjivanja } \\
\hline & & & 2007 & 2008 & 2009 & 2010 & 2011 & 2012 \\
\hline & & & \multicolumn{6}{|c|}{ Rating / Ocjenjivanje } \\
\hline Norway spruce / norveška jela & $2-4$ & 7. 4.2006 & 0.2 & 0.8 & 1.8 & 2.8 & 3.2 & 3.6 \\
\hline Norway spruce / norveška jela & $4-8$ & 28.5 .2007 & 1 & 1.4 & 2.5 & 3.7 & 4.0 & 1 \\
\hline Larch / ariš & $2-4$ & 15.5 .2008 & 1 & 1 & 0.0 & 0.0 & 0.0 & 0.0 \\
\hline
\end{tabular}




\section{Acknowledgments - Zahvale}

Authors would like to acknowledge the Slovenian Research Agency for financial support in the framework of the program Wood and Lignocellulosic Composites (P4-0015) and project (L4-5517). Technical support of Mr. Robert Sitar is appreciated as well.

\section{REFERENCES}

5. LITERATURA

1. Augusta, U., 2007: Untersuchung der natürlichen Dauerhaftigkeit wirtschaftlich bedeutender Holzartenbei verschiedener Beanspruchung im Außenbereich. Dissertation, University of Hamburg.

2. Brischke, C.; Meyer, L.; Alfredsen, G.; Humar, M.; Francis, L.; Flæte, P.O.; Larsson-Brelid, P., in press: Natural durability of timber exposed above ground - a survey. Drvna industrija.

3. Brischke, C.; Rapp, A. O., 2008: Dose-response relationships between wood moisture content, wood temperature and fungal decay determined for 23 European field test sites. Wood Sci. Tech. 42: 507-518. http://dx.doi.org/10.1007/s00226-008-0191-8

4. Collardet, J.; Besset, J., 1988: Bois commerciaux, Tome 1, les résineux (conifères). CTBA, 278 p.

5. Cote, W. A.; Day, A. C.; Simson, B. W., 1966: Studies on larch arabinogalactan. I. The distribution of arabionogalactan in Larch wood. Holzforschung 20: 178-192. http://dx.doi.org/10.1515/hfsg.1966.20.6.178

6. Curnel, Y.; Jacques, D.; Gierlinger, N.; Paques, L. E., 2008: Variation in the decay resistance of larch to fungi. Ann. For. Sci. 65: 810-818.

http://dx.doi.org/10.1051/forest:2008062

7. Eaton, R. A.; Hale, M. D. C., 1993: Natural durability. In: Hall C (eds.) Wood: decay, pests and protection, vol 1. Chapman and Hall, London, pp. 311-318.

8. EN 113. 2004: Wood preservatives; Determination of the toxic values against wood destroying basidiomycetes cultured an agar medium.

9. EN 252. 1989: Field test method for determining the relative protective effectiveness of a wood preservative in ground contact.

10. EN 350-1. 1994: Durability of wood and wood-based products - Natural durability of solid wood - Part 1 : Guide to the principles of testing and classification of the natural durability of wood.

11. Flæte, P. O.; Alfredsen, G.; Evans, F. G., 2011: Natural durability of wood tested in different environments in Northern Europe. IRG/WP 11-10747

12. Gierlinger, N.; Jacques, D.; Schwanninger, M.; Wimmer, R.; Paques, L. E., 2004: Heartwood extractives and lignin content of different larch species (Larix sp.) and relationships to brown-rot decay-resistance. Trees. 18: 230-236. http://dx.doi.org/10.1007/s00468-003-0300-0

13. Giwa, S. A. O.; Swan, E. P., 1975: Heartwood extractives of a western larch tree (Larix occidentalis Nutt.). Wood Fiber. 7: 216-221.
14. Green, F.; Highley, T. L., 1997: Mechanism of brown-rot decay: paradigm or paradox. International Biodeterior Biodegrad. 39: 113-124.

http://dx.doi.org/10.1016/S0964-8305(96)00063-7

15. Hawley, L. F.; Fleck, L. C.; Richards, C. A., 1924: The relation between natural durability and chemical composition in wood. Ind. Eng. Chem. 16: 699-706. http://dx.doi.org/10.1021/ie50175a015

16. Hovelstad, H.; Leirset, I.; Oyaas, K.; Fiksdah, A., 2006: Screening Analyses of Pinosylvin Stilbenes, Resin Acids and Lignans in Norwegian Conifers. Molecules 2006, 11, 103-114. http://dx.doi.org/10.3390/11010103

17. Örsa, F.; Holmbom, B.; Thornton, J., 1997: Dissolution and dispersion of spruce components into hot water. Wood Sci. and Tech. 31: 279-290. http://dx.doi.org/10.1007/BF00702615

18. Rapp, A. O.; Augusta, U., 2004: The full guideline for the »double layer test method « - A Field test method for determinating the durability of wood out of ground. IRG/ WP 04-20290.

19. Schmidt, O., 2007: Indoor wood-decay basidiomycetes: damage, causal fungi, physiology, identification and characterization, prevention and control. Mycol. Prog. 6: 261-279. http://dx.doi.org/10.1007/s11557-007-0534-0

20. Solár, R.; Kurjatko, S.; Mamon, M.; Košíková, B.; Neuschlová, E.; Výbohová, E.; Hudec, J., 2007: Selected properties of beech wood degraded by brown-rot fungus Coniophora puteana. Drvna Ind. 58: 3-11.

21. Srinivasan, U.; Ung, T.; Taylor, A.; Cooper, P. A., 1999: Natural durability and waterborne treatability of tamarack. For. Prod. J. 49: 82-87.

22. Venäläinen, M.; Harju, A. M.; Nikkanen, T.; Paajanen, L.; Velling, P.; Viitanen, H., 2001: Genetic variation in the decay resistance of Siberian larch (Larix sibirica Ledeb.) wood. Holzforschung. 55: 1-6. http://dx.doi.org/10.1515/HF.2001.001

23. Verkasalo, E., 1992: Relationships of the modulus of elasticity and the structure of Finnish Scots pine wood. Silva Fennica. $26: 155-168$.

24. Wagenführ, R., 1996: Holzats. Leipzig, Fachbuchverlag: 688.

25. Welzbacher, C. R; Brischke, C.; Rapp, A. O.; Koch, S.; Hofer, S., 2009: Performance of thermally modified timber (TMT) in outdoor application - durability, abrasion and optical appearance. Drvna Ind. 60: 75-82.

\section{Corresponding address:}

Associate Professor MIHA HUMAR, Ph.D.

University of Ljubljana

Biotechnical Faculty

Department of Wood Science and Technology

Jamnikarjeva 101

SI-1000 Ljubljana, SLOVENIA

e-mail: miha.humar@bf.uni-lj.si 